\title{
Energy utilisation and growth performance of chicken fed diets containing graded levels of supplementary bacterial phytase
}

\author{
V. Pirgozliev ${ }^{1 *} \dagger$ and M. R. Bedford ${ }^{2}$ \\ ${ }^{1}$ Avian Science Research Centre, Scottish Agricultural College, Auchincruive, Ayr KA6 5HW, UK \\ ${ }^{2}$ AB Vista Feed Ingredients, Woodstock Court, Blenheim Road, Marlborough Business Park, Marlborough, \\ Wiltshire SN8 $4 A N$, UK
}

(Submitted 28 September 2011 - Final revision received 1 February 2012 - Accepted 13 February 2012 - First published online 13 April 2012)

\section{Abstract}

A total of 364 female Ross 308 chicks ( 1 d old) were used in the present study conducted in floor pens to investigate the effects of graded levels of supplementary bacterial phytase on dietary energy utilisation and growth performance. For this purpose, four maize-soyabean-based diets were offered to the birds from 0 to $21 \mathrm{~d}$ of age. These included a suboptimal P negative control ( NC, $3.0 \mathrm{~g} / \mathrm{kg}$ non-phytate P), NC $+250 \mathrm{phytase}$ units (FTU) $/ \mathrm{kg}$ feed, NC $+500 \mathrm{FTU}$ and NC +2500 FTU. The effect of phytase activity on bird growth performance was best described as a linear relationship between increasing dose and increased feed intake $(P<0 \cdot 001)$, but was quadratic for body-weight gain $(P=0 \cdot 002)$ and feed efficiency $(P=0.023)$. There was no significant response $(P>0.05)$ of dietary apparent metabolisable energy (AME) to supplementary phytase. The birds fed phytase increased their retention of total carcass energy in a linear fashion $(P=0 \cdot 009)$ with increased phytase dose. The efficiency of dietary AME used for overall carcass energy retention also improved $(P=0 \cdot 007)$ in a linear manner with increased dietary phytase activity. Dietary net energy for production $\left(\mathrm{NE}_{\mathrm{p}}\right)$ increased $(P=0.047)$ with an increase in phytase dose following a linear pattern, as an increase of 100 FTU increased dietary net energy by $15.4 \mathrm{~J}$ (estimated within the range of doses used in the present experiment). Dietary $\mathrm{NE}_{\mathrm{p}}$ was more highly correlated with performance criteria than dietary AME, and it seems to be a more sensitive way to evaluate broiler response to phytase supplementation.

Key words: Chickens: Bacterial phytase: Net energy: Energy retention

Diet composition is a major variable in poultry production. There is a wide range of feedstuffs available to the feed industry and the decision to use a specific feedstuff is often price dependent. The price of feedstuffs depends, among other factors, on their nutrient composition and the concentration of available energy. The cost of supplying available energy accounts for about half of the cost of a broiler chicken feed ${ }^{(1)}$. The availability of dietary energy in turn depends on the availability of carbohydrates, protein and starch, all of which may be impaired by anti-nutritive factors. Dietary phytate, a mixture of phytic acid and its salts, has been viewed as an anti-nutrient due to its ability to chelate minerals and react with starch and protein, reducing their availability for poultry ${ }^{(2,3)}$. Poultry do not produce meaningful quantities of endogenous phytase ${ }^{(4,5)}$ and, as a result, the detrimental effects of phytate in poultry diets can be ameliorated by the addition of microbial phytases.
So far, the majority of the studies evaluating the effect of phytase on available energy have been performed using the metabolisable energy system, i.e. dietary apparent metabolisable energy (AME). Although dietary AME is widely used to describe the available energy concentration in poultry feedstuffs, diets with the same AME are not necessarily used with equal efficiency when fed to poultry ${ }^{(6-9)}$. Work with exogenous phytases has shown that the improvement in performance is closely associated with destruction of dietary phytate, coupled with an improvement in the digestion and absorption of nutrients, although the influence of phytase on dietary AME per se has been inconsistent. Whereas some authors found an increase in dietary AME in response to phytase ${ }^{(10,11)}$, others ${ }^{(12,13)}$ did not.

Dietary net energy is the metabolisable energy of the feed corrected for losses that result from the assimilation of dietary ingredients, frequently termed the heat increment of digestion.

\footnotetext{
Abbreviations: AME, apparent metabolisable energy; $\mathrm{CF}_{\mathrm{r}}$, retained carcass fat; $\mathrm{CP}_{\mathrm{r}}$, retained carcass protein; FCE, feed conversion efficiency; FI, feed consumed from $1 \mathrm{~d}$ old to the end of the study at day 21; FTU, phytase units; GE, gross energy; $\mathrm{HP}_{\mathrm{f}}$, heat production per kg feed intake; HP $\mathrm{t}_{\mathrm{t}}$, total heat production; $K_{\mathrm{re}}$, efficiency of apparent metabolisable energy used for energy retention; $\mathrm{NC}$, negative control; $\mathrm{NE}_{\mathrm{p}}$, net energy for production; $\mathrm{RE}_{\mathrm{c}}$, total energy retained in the carcass; $\mathrm{RE}_{\mathrm{f}}$, energy retained as fat; $\mathrm{RE}_{\mathrm{p}}$, energy retained as protein; WG, weight gain.
}

*Corresponding author: Dr V. Pirgozliev, fax +44 1952 814783, email vpirgozliev@harper-adams.ac.uk 
The remaining net energy is available for both maintenance and production.

However, there is a lack of knowledge on the effect of supplemental microbial phytase on dietary net energy for production $\left(\mathrm{NE}_{\mathrm{p}}\right)$. Pirgozliev et al. ${ }^{(13)}$ demonstrated a positive dose-response relationship between phytase and dietary $\mathrm{NE}_{\mathrm{p}}$ in caged chickens.

Thus, the objective of the present study was to quantify the responses and inter-relationships in dietary $\mathrm{NE}_{\mathrm{p}}$, determined by a comparative slaughter technique, resulting from feeding graded activities of supplementary phytase to chickens reared in floor pens. Bird growth parameters and energy metabolism were also determined.

\section{Materials and methods \\ Diet formulation}

An Escherichia coli-derived phytase (Quantum ${ }^{\mathrm{TM}}$ EC 3.1.3.26; AB Vista Feed Ingredients) was used in the present experiment. A total of four experimental diets were prepared. A maize-based control diet, hereafter named negative control (NC), was formulated to be adequate in protein and energy but lower in nonphytate $\mathrm{P}$ content $(3.0 v .4 .7 \mathrm{~g} / \mathrm{kg}$ diet recommended by the National Research Council ${ }^{(14)}$; Table 1). The remaining three diets were the NC supplemented with phytase $(250,500$ or 2500 phytase activity units (FTU)/kg diet, i.e. NC + 250 FTU, $\mathrm{NC}+500 \mathrm{FTU}$ and $\mathrm{NC}+2500 \mathrm{FTU})$. The enzyme was added to the diets in powder form and all diets were fed as a mash. Titanium dioxide was added to the diets $(5 \mathrm{~g} / \mathrm{kg})$ as an indigestible marker to enable determination of dietary AME.

\section{Husbandry and sample collection}

A total of 364 female Ross 308 chicks ( 1 d old) were used in the present experiment. The Animal Experimental Committee of the Scottish Agricultural College approved the study. At the beginning of the experiment, four birds from the general group, selected at random, were killed by cervical dislocation, and stored in a freezer at $-20^{\circ} \mathrm{C}$ for analysis. The rest of the birds were allocated to twenty-four floor pens, fifteen birds in each pen, from 0 to $21 \mathrm{~d}$ of age. Each diet was offered ad libitum to birds housed in one of six pens in a randomised complete block design. The room was kept at a temperature of approximately $31^{\circ} \mathrm{C}$ at day 0 , and this was gradually reduced to approximately $22^{\circ} \mathrm{C}$ at the end of the $21 \mathrm{~d}$ feeding period. Relative humidity was maintained at about $50 \%$. The light regimen was $23 \mathrm{~h}$ light and $1 \mathrm{~h}$ dark. The birds were group-weighed on a per-pen basis at the beginning and at the end of the study, and the average bird weight gain (WG) and feed conversion efficiency (FCE) were determined.

At the end of the study ( $21 \mathrm{~d}$ ), two birds with a body weight nearest to the pen average from each pen were transferred to one of twenty-four wire-meshed metabolism cages. The birds selected were kept in the cages for approximately $4 \mathrm{~h}$ and excreta were collected in the trays beneath. During this period, water was provided ad libitum but feed was withdrawn to minimise the contribution of undigested feed to the estimate
Table 1. Ingredient composition of the experimental control diet

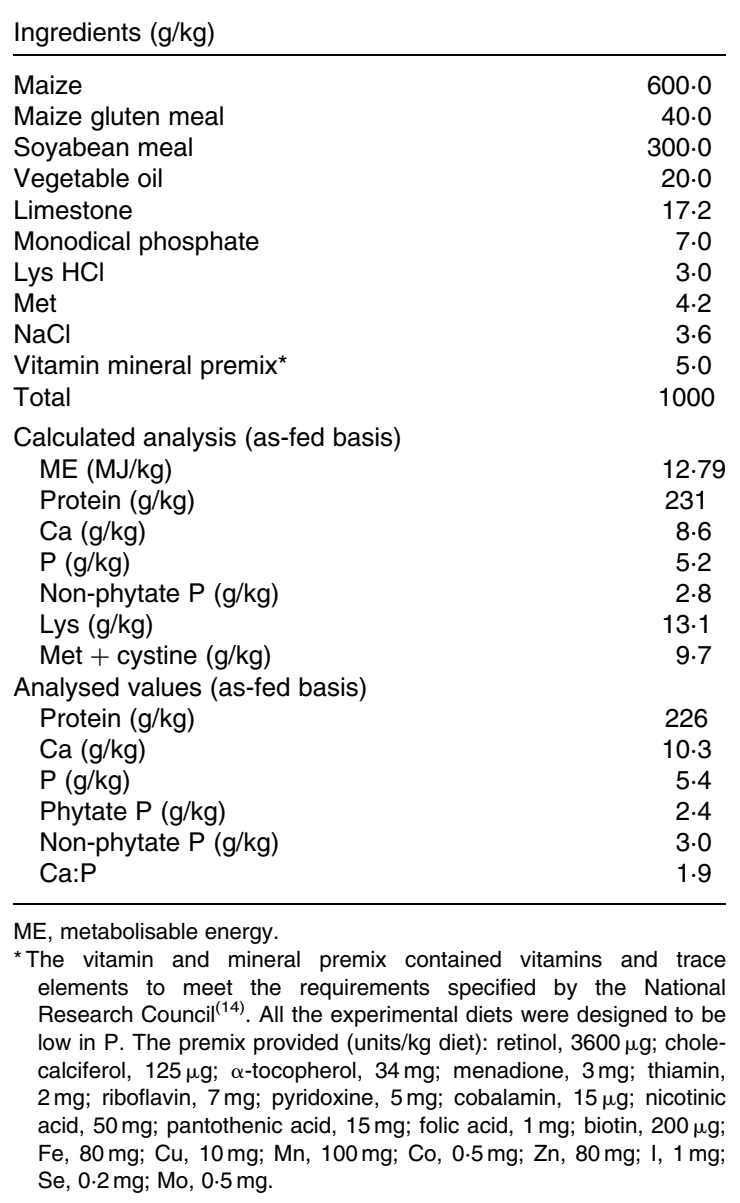

of carcass energy retention. The birds were then weighed and killed by cervical dislocation. A comparative slaughter technique was applied to determine retention of nutrients. The carcases of the birds, including intestines and feathers, from each cage were frozen and then minced (Hobart A 200; The Hobart Manufacturing Company Limited). The minced carcases of the birds of each cage were pooled, thoroughly mixed and sampled, and used for following calculations. The carcass samples were freeze-dried, and carcass fat and crude protein were determined and used for following calculations based on average pen bird weight. The same procedure was applied to the carcases of four birds taken at the start of the experiment and the data were used to determine carcass fat, protein and gross energy (GE) retention for the experimental period. It was assumed that carcass energy stored in the form of glycogen was small relative to the total carcass energy stored.

\section{Chemical analysis}

The experimental diets and the excreta were analysed for GE and titanium dioxide in order to determine dietary AME. GE was determined using a bomb calorimeter (Parr 6200; Parr Instruments Company). Titanium dioxide concentration in feed and excreta was determined using the method of 
Short et al. ${ }^{(15)}$. Dietary Ca and total P were determined by inductively coupled plasma emission spectrometry (Optima 4300 DV Dual 150 View ICP-OE spectrometer; Perkin Elmer ${ }^{(16)}$. The content of dietary phytate $\mathrm{P}$ was determined employing the method of McCance \& Widdowson ${ }^{(17)}$. The $\mathrm{N}$ content of feed and freeze-dried carcass samples was analysed by the Kjeldahl method (Kjeltec 1035 Autoanalyser; Perstorp Analytical, Hoganas), Association of Official Analytical Chemists (AOAC) $984.13^{(18)}$. The crude protein values were obtained as $\mathrm{N} \times 6 \cdot 25$. The crude fat in the feed and carcass samples was extracted using a Soxtec system (Foss UK Limited) according to AOAC $920.39^{(18)}$.

\section{Calculations}

Dietary AME (MJ/kg) was calculated as follows:

$$
\mathrm{AME}=\mathrm{GE}_{\mathrm{f}}-\left(\mathrm{GE}_{\mathrm{e}} \times\left(\mathrm{Ti}_{\text {feed }} / \mathrm{Ti}_{\text {excreta }}\right)\right),
$$

where $\mathrm{GE}_{\mathrm{f}}$ is the $\mathrm{GE}(\mathrm{MJ} / \mathrm{kg})$ of the feed; $\mathrm{GE}_{\mathrm{e}}$ is the $\mathrm{GE}$ $(\mathrm{MJ} / \mathrm{kg})$ of the excreta; $\mathrm{Ti}_{\text {feed }}$ is the concentration of titanium dioxide in the diets $(\mathrm{g} / \mathrm{kg})$; and $\mathrm{Ti}_{\text {excreta }}$ is the concentration of titanium dioxide in the excreta $(\mathrm{g} / \mathrm{kg})$.

The total carcass GE retained in the body was obtained as the sum of the carcass GE retained as protein and fat.

The total carcass protein retention $\left(\mathrm{CP}_{\mathrm{r}}, \mathrm{g} / \mathrm{bird}\right)$ was calculated as follows:

$$
\mathrm{CP}_{\mathrm{r}}=\left(\mathrm{N}_{21}-\mathrm{N}_{1}\right) \times 6 \cdot 25 \text {, }
$$

where $\mathrm{N}_{21}$ is the $\mathrm{N}(\mathrm{g})$ in chicken carcases at $21 \mathrm{~d}$ old; $\mathrm{N}_{1}$ is the $\mathrm{N}(\mathrm{g})$ in chicken carcases at the beginning of the experiment at $1 \mathrm{~d}$ old; and 6.25 is the coefficient used to calculate the protein retained in the body.

The value of the carcass $\mathrm{GE}$ retained as protein $\left(\mathrm{RE}_{\mathrm{p}}\right)$ was calculated as:

$$
\mathrm{RE}_{\mathrm{p}}=\mathrm{CP}_{\mathrm{r}} \times 23.6 \mathrm{MJ} \text {, }
$$

where $\mathrm{CP}_{\mathrm{r}}(\mathrm{kg})$ is multiplied by $23.6 \mathrm{MJ}$, the amount of energy in $1 \mathrm{~kg}$ of protein according to Okumura \& Mori ${ }^{(19)}$.

The total carcass fat retention $\left(\mathrm{CF}_{\mathrm{r}}, \mathrm{g} /\right.$ bird $)$ was obtained similarly to $\mathrm{CP}_{\mathrm{r}}$ as follows:

$$
\mathrm{CF}_{\mathrm{r}}=\left(\mathrm{F}_{21}-\mathrm{F}_{1}\right)
$$

where $F_{21}$ is the fat $(\mathrm{g})$ in chicken carcases at $21 \mathrm{~d}$ old; $F_{1}$ is the fat $(\mathrm{g})$ in chicken carcases at the beginning of the experiment at $1 \mathrm{~d}$ old

The value of the carcass GE retained as fat $\left(\mathrm{RE}_{\mathrm{f}}\right)$ was obtained as follows:

$$
\mathrm{RE}_{\mathrm{f}}=\mathrm{CF}_{\mathrm{r}} \times 39 \cdot 12 \mathrm{MJ} \text {, }
$$

where $\mathrm{CF}_{\mathrm{r}}(\mathrm{kg})$ is multiplied by $39 \cdot 12 \mathrm{MJ}$, the amount of energy in $1 \mathrm{~kg}$ of fat according to Okumura \& Mori ${ }^{(19)}$.

The total energy retained in the carcass $\left(\mathrm{RE}_{\mathrm{C}}\right)$ was calculated as follows:

$$
\mathrm{RE}_{\mathrm{c}}(\mathrm{MJ})=\left(\mathrm{RE}_{\mathrm{p}}+\mathrm{RE}_{\mathrm{f}}\right)
$$

$\mathrm{NE}_{\mathrm{p}}(\mathrm{MJ} / \mathrm{kg})$ was calculated using the following equation:

$$
\mathrm{NE}_{\mathrm{p}}(\mathrm{MJ} / \mathrm{kg})=\left(\mathrm{RE}_{\mathrm{c}}\right) / \mathrm{FI} \text {, }
$$

where FI is the feed $(\mathrm{kg})$ consumed from $1 \mathrm{~d}$ old to the end of the study at day 21 .
The efficiency of AME used for energy retention $\left(K_{\mathrm{re}}\right)$ was calculated as the $\mathrm{RE}_{\mathrm{C}}$ divided by AME intake.

$$
K_{\mathrm{re}}=\mathrm{RE}_{\mathrm{c}} / \mathrm{AME} \text { intake, }
$$

where AME intake is the FI ( $\mathrm{kg}$ ) for the experimental period multiplied by determined metabolisable energy $(\mathrm{MJ} / \mathrm{kg})$ of the diets.

\section{Heat production}

The total heat production $\left(\mathrm{HP}_{\mathrm{t}}\right)$ of the birds from $1 \mathrm{~d}$ old to $21 \mathrm{~d}$ old, which consists of the energy for tissue retention, maintenance and the heat increment of production, was calculated as the difference between dietary AME intake and $\mathrm{RE}_{\mathrm{c}}$ :

$$
\mathrm{HP}_{\mathrm{t}}(\mathrm{MJ})=\mathrm{AME} \text { intake }-\mathrm{RE}_{\mathrm{c}} \text {. }
$$

The heat production per $\mathrm{kg}$ feed intake $\left(\mathrm{HP}_{\mathrm{f}}, \mathrm{MJ} / \mathrm{kg}\right.$ feed intake) was also calculated:

$$
\mathrm{HP}_{\mathrm{f}}(\mathrm{MJ} / \mathrm{kg} \text { feed intake })=\left(\mathrm{HP}_{\mathrm{t}}\right) / \mathrm{FI},
$$

where $\mathrm{HP}_{\mathrm{t}}$ is the total heat production of the birds from $1 \mathrm{~d}$ old to $21 \mathrm{~d}$ old $(\mathrm{MJ})$, and FI ( $\mathrm{kg}$ ) consumed.

The $\mathrm{NE}_{\mathrm{p}}: \mathrm{HP}_{\mathrm{f}}$ ratio describes the relative efficiency of the use of metabolisable energy between body energy retention and heat production, implicit that a more efficient split in energy towards production rather than heat increment is related to a higher ratio.

\section{Statistical analyses}

The observational unit was the floor pen. Statistical analyses were performed using GenStat (11th edition; Lawes Agricultural Trust, VSN International Limited). The data were analysed by ANOVA. AME intake was used as a covariate in the analysis of energy utilisation response data, because of the possible influence of variation in AME intake on the energy utilisation response criteria. Orthogonal polynomials were used to compare treatment differences for linear and quadratic relationships with increasing phytase activity (using the log phytase activity). Linear regression analysis was used to assess the relationship between supplemental phytase activity and dietary $\mathrm{NE}_{\mathrm{p}}$. Correlation coefficients were also generated to test for a possible relationship between the different variates. In all instances, differences were reported as significant at $P<0.05$ and trends were noted when $P$ was 0.05 or greater and less than $0 \cdot 10$.

\section{Results}

The analysed chemical composition of the basal diet is shown in Table 1. The analysed protein content was lower, although the analysed $\mathrm{Ca}$ content was higher than the calculated values. The contents of dietary total and non-phytate $\mathrm{P}$ were close to the calculated values.

Table 2 shows the data on the growth performance of chickens and dietary AME. The effect of phytase activity on the growth performance of broilers was best described as a quadratic relationship between increasing dose and increased 
Table 2. Effect of the experimental diets on bird growth performance, dietary apparent metabolisable energy (AME) and dietary AME intake from 0 to $21 \mathrm{~d}$ of age

\begin{tabular}{lcccccrr}
\hline & NC $\dagger$ & NC +250 FTU & NC +500 FTU & NC + 2500FTU & SEM & $L$ & $Q$ \\
\hline Feed intake (g/bird) & 829 & 874 & 913 & 952 & 16.9 & $<0.001$ & 0.096 \\
Weight gain (g/bird) & 599 & 618 & 683 & 730 & 13.45 & $<0.001$ & 0.002 \\
FCE & 0.723 & 0.707 & 0.749 & 0.769 & 0.0129 & 0.054 & 0.023 \\
AME (MJ/kg) & 13.33 & 13.42 & 13.51 & 13.27 & 0.140 & 0.909 & 0.271 \\
AME intake (MJ) & 11.05 & 11.72 & 12.35 & 12.63 & 0.294 & 0.001 & 0.402 \\
\hline
\end{tabular}

NC, negative control; FTU, phytase activity (units $/ \mathrm{kg}$ ) in diet; $L$, linear; $Q$, quadratic.

* There were six observations per treatment.

†NC containing $3.0 \mathrm{~g}$ non-phytate $\mathrm{P} / \mathrm{kg}$.

WG $(P=0.002)$ and FCE $(P=0.023)$ and linear with FI $(P<0.001)$. Although there were no significant linear or quadratic responses $(P>0.05)$ of dietary AME to phytase, there was a linear relationship $(P=0.001)$ between increasing phytase activity and increased AME intake (Table 2), which was clearly related to the intake and not to the AME component.

Table 3 shows the data on the parameters describing the energy metabolism of the experimental birds. Overall, birds fed phytase tended ( $P=0.059)$ to increase the retention of carcass fat and increased total energy retention in a linear fashion $(P=0.009)$ with increased phytase dose, which is in agreement with the growth performance and energy intake data. The efficiency of AME used for overall carcass energy retention $\left(K_{\mathrm{re}}\right)$ improved $(P=0.007)$ in a linear manner with increased dietary phytase dose.

The $\mathrm{NE}_{\mathrm{p}}$ content of the diet increased $(P=0.047)$ with increasing phytase dose in a linear pattern (estimated within the range of doses used in the present experiment; Table 3). An increase of $100 \mathrm{FTU}$ raised dietary $\mathrm{NE}_{\mathrm{p}}$ by $15.4 \mathrm{~J}\left(\mathrm{NE}_{\mathrm{p}}=5.5\right.$ $(\operatorname{se} 0 \cdot 12)+0.154(\operatorname{se} 0.093) \log \mathrm{FTU})$. The $\mathrm{NE}_{\mathrm{p}}: \mathrm{HP}_{\mathrm{f}}$ ratio also increased in a linear pattern $(P=0.006)$ with increasing dietary phytase dose.

Table 4 shows the correlation coefficients of the growth and energy utilisation response criteria. WG correlated well with dietary $\mathrm{NE}_{\mathrm{p}}(r 0.942 ; P<0.001)$, although there was no correlation with dietary AME $(P>0 \cdot 05)$. Similarly, FCE was correlated with $\mathrm{NE}_{\mathrm{p}}(r \quad 0.764 ; P<0.001)$ but not with dietary AME $(P>0.05)$.

\section{Discussion}

The analysed dietary protein and $\mathrm{Ca}$ contents differed from the calculated values, which could probably be due to the differences between the composition of the actual ingredients that were used in the present study and the values given by the National Research Council ${ }^{(14)}$ for the same ingredients.

The experimental diets were formulated to be equally deficient in P and supplemented with graded levels of exogenous phytase to allow testing of the slope of energy metabolism responses to phytase dosage. The improvement in performance observed when phytase is fed in low-P diets has been reported quite extensively ${ }^{(11,20,21)}$. In the present study, the WG of the birds fed 2500 FTU was close to that of commercially reared birds at the same age (Aviagen Limited), and the chicks were about $15 \%$ heavier and converting feed 6.4\% more efficiently compared with birds fed the $\mathrm{NC}$. The $\mathrm{NE}_{\mathrm{p}}$ values of the phytase-supplemented diets were also in the range expected for a standard poultry feed ${ }^{(13,22,23)}$. This is despite the reduction of $36 \%$ non-phytate $\mathrm{P}$ compared with that recommended by the National Research Council ${ }^{(14)}$. It is noteworthy that the continuing positive response of bird growth performance to supra-dosages of exogenous phytase is in agreement with previous research ${ }^{(13,24)}$, and shows that the recently recommended $500 \mathrm{FTU} / \mathrm{kg}$ seems to be much lower than the potential commercial optimum.

Further partitioning of the bird carcass into composition of gain showed that protein was responsible for the larger share of carcass energy than fat, which is in agreement with previous

Table 3. Energy metabolism of chickens (data based on the feeding period from 0 to $21 \mathrm{~d}$ of age)*

\begin{tabular}{|c|c|c|c|c|c|c|c|}
\hline Variates & $\mathrm{NC}+$ & $\mathrm{NC}+250 \mathrm{FTU}$ & $\mathrm{NC}+500 \mathrm{FTU}$ & $\mathrm{NC}+2500 \mathrm{FTU}$ & SEM & $L$ & $Q$ \\
\hline $\mathrm{CP}_{\mathrm{r}}(\mathrm{g} / \mathrm{bird})$ & 113.5 & $108 \cdot 1$ & $120 \cdot 9$ & $123 \cdot 8$ & $5 \cdot 17$ & 0.669 & 0.119 \\
\hline $\mathrm{CF}_{\mathrm{r}}(\mathrm{g} / \mathrm{bird})$ & $50 \cdot 7$ & $61 \cdot 6$ & $59 \cdot 3$ & $64 \cdot 2$ & $4 \cdot 34$ & 0.059 & 0.999 \\
\hline $\mathrm{RE}_{\mathrm{c}}(\mathrm{MJ})$ & $4 \cdot 66$ & 4.96 & $5 \cdot 18$ & 5.43 & 0.132 & 0.009 & 0.146 \\
\hline $\mathrm{RE}_{\mathrm{p}}(\mathrm{MJ})$ & $2 \cdot 68$ & 2.55 & $2 \cdot 85$ & $2 \cdot 92$ & 0.122 & 0.669 & 0.119 \\
\hline$R E_{f}(M J)$ & 1.98 & 2.41 & $2 \cdot 32$ & 2.51 & 0.170 & 0.059 & 0.999 \\
\hline$K_{\mathrm{re}}$ & 0.390 & 0.416 & 0.436 & 0.456 & 0.0110 & 0.007 & 0.165 \\
\hline $\mathrm{NE}_{\mathrm{p}}(\mathrm{MJ} / \mathrm{kg})$ & $5 \cdot 31$ & $5 \cdot 61$ & $5 \cdot 82$ & 5.95 & 0.164 & 0.047 & 0.562 \\
\hline $\mathrm{HP}_{\mathrm{t}}(\mathrm{MJ})$ & $7 \cdot 26$ & 6.97 & 6.75 & 6.49 & 0.132 & 0.009 & 0.146 \\
\hline $\mathrm{HP}_{\mathrm{f}}(\mathrm{MJ} / \mathrm{kg})$ & $8 \cdot 31$ & 7.89 & 7.56 & 7.09 & 0.158 & 0.002 & 0.031 \\
\hline $\mathrm{NE}_{\mathrm{p}}: \mathrm{HP}_{\mathrm{f}}$ & 0.632 & 0.716 & 0.784 & 0.850 & 0.0349 & 0.006 & 0.139 \\
\hline
\end{tabular}

NC, negative control; FTU, phytase activity (units/kg) in diet; $L$, linear; $Q$, quadratic; $\mathrm{CP}_{\mathrm{r}}$, retained carcass protein ( $\mathrm{g} / \mathrm{bird}$ ); $\mathrm{CF}_{\mathrm{r}}$, retained carcass fat $(\mathrm{g} / \mathrm{bird}) ; \mathrm{RE}_{\mathrm{c}}$, total carcass energy retained in a bird from 0 to $21 \mathrm{~d}$ of age; $R E_{\mathrm{p}}$, carcass gross energy retained as carcass protein; $R E_{f}$, carcass gross energy retained as carcass fat; $K_{r e}$, efficiency of dietary apparent metabolisable energy retention; $N E_{p}$, net energy for production (carcass energy retained per $\mathrm{kg}$ feed intake); $\mathrm{HP}_{\mathrm{t}}$, total heat production from 0 to $21 \mathrm{~d}$ of age; $H P_{\mathrm{f}}(\mathrm{MJ})$, heat production per $\mathrm{kg}$ feed intake.

* There were six observations per treatment.

†NC containing $3.0 \mathrm{~g}$ non-phytate $\mathrm{P} / \mathrm{kg}$. 
Table 4. Correlation matrix for the growth performance and dietary energy response criteria of broiler chickens to dietary phytase supplementation (data based on the feeding period from 0 to $21 \mathrm{~d}$ of age) ${ }^{\star}$

\begin{tabular}{|c|c|c|c|c|c|c|c|c|c|c|c|}
\hline & Intake & Gain & FCE & AME & $\mathrm{AME}_{\text {int }}$ & $\mathrm{RE}_{\mathrm{c}}$ & $\mathrm{NE}_{\mathrm{p}}$ & $\mathrm{HP}_{\mathrm{t}}$ & $\mathrm{HP}_{\mathrm{f}}$ & $\mathrm{NE}_{\mathrm{p}}: \mathrm{HP}_{\mathrm{f}}$ & $K_{\mathrm{re}}$ \\
\hline Intake & 1.000 & & & & & & & & & & \\
\hline Gain & 0.974 & 1.000 & & & & & & & & & \\
\hline FCE & 0.827 & 0.932 & 1.000 & & & & & & & & \\
\hline AME & -0.087 & -0.175 & -0.284 & 1.000 & & & & & & & \\
\hline $\mathrm{AME}_{\text {int }}$ & 0.989 & 0.953 & 0.794 & 0.059 & 1.000 & & & & & & \\
\hline $\mathrm{RE}_{\mathrm{c}}$ & 0.999 & 0.968 & 0.811 & -0.088 & 0.988 & 1.000 & & & & & \\
\hline $\mathrm{NE}_{\mathrm{p}}$ & 0.989 & 0.942 & 0.764 & -0.049 & 0.998 & 0.990 & 1.000 & & & & \\
\hline $\mathrm{HP}_{\mathrm{t}}$ & -0.999 & -0.971 & -0.818 & 0.104 & -0.986 & -0.999 & -0.988 & 1.000 & & & \\
\hline$H P_{f}$ & -0.997 & -0.975 & -0.833 & 0.159 & -0.976 & -0.997 & -0.978 & 0.998 & 1.000 & & \\
\hline$N E_{p}: H P_{f}$ & 0.999 & 0.970 & 0.816 & -0.068 & 0.992 & 0.999 & 0.993 & -0.999 & -0.996 & 1.000 & \\
\hline$K_{\mathrm{re}}$ & 0.999 & 0.967 & 0.810 & -0.066 & 0.992 & 0.999 & 0.993 & -0.999 & -0.996 & 0.999 & 1.000 \\
\hline
\end{tabular}

$\mathrm{FCE}$, feed conversion efficiency; $\mathrm{AME}$, apparent metabolisable energy; $\mathrm{AME}_{\mathrm{int}}, \mathrm{AME}$ intake; $\mathrm{RE}_{\mathrm{c}}$, total energy retained in the carcass; $\mathrm{NE}_{\mathrm{p}}$, net energy for production; $\mathrm{HP}_{\mathrm{t}}$, total heat production; $\mathrm{HP}_{\mathrm{f}}$, heat production per $\mathrm{kg}$ feed intake; $K_{\mathrm{re}}$, efficiency of $\mathrm{AME}$ use for energy retention.

${ }^{*} \mathrm{df}=9$, correlation coefficients greater than 0.602 and 0.735 are statistically significant at a $5 \%(P<0.05)$ and $1 \%$ level $(P<0.001)$, respectively.

reports $^{(25)}$. Research by Leeson \& Summers ${ }^{(26)}$ also showed that at an early stage of growth, broilers are depositing proportionally more carcass protein than fat, further supporting the results. No differences in carcass protein:fat ratios were observed between the treatments (data not shown).

The improvement in growth performance with phytase supplementation was coupled with an increase in dietary AME intake but not with AME per se, suggesting that phytase influences AME intake more through feed intake than through energy metabolisability.

The efficiency of dietary AME use for tissue energy retention is in agreement with previous reports when chickens at similar age were fed supplementary phytase ${ }^{(20,27)}$. A linear increase in $K_{\text {re }}$ due to phytase supplementation is in accord with the higher $\mathrm{NE}_{\mathrm{p}}$ values, which does not correlate with the effects on dietary AME. The effect of phytase addition on the improvement of $\mathrm{NE}_{\mathrm{p}}$ but not of AME suggests that phytase enables nutrients to be digested and absorbed in the proximal parts of the small intestine when in non-supplemented diets, these nutrients may have entered the distal part of the small intestine where they may be fermented by the bacterial population. Birds do not efficiently utilise the volatile fatty acids produced ${ }^{(28)}$, thus the variation in the amount of bacterial fermentation that occurs between different experiments may explain the variability in AME response to phytase in published data. The literature suggests that although phytase supplementation does not always improve dietary metabolisable energy, it usually improves intake and gain ${ }^{(13,29)}$, the former being an implicit part of AME intake, which was well correlated with $\mathrm{NE}_{\mathrm{p}}$. With increased AME intake, birds will have consumed more energy per d per unit of body weight, resulting in proportionately more of total intake being available for production as opposed to maintenance. The close relationship between AME intake and $K_{\mathrm{re}}$ is in agreement with a previous report ${ }^{(13)}$ and further supports this hypothesis. Thus, feeding phytase may improve energy retention as much, if not more, through increasing total energy intake, thereby increasing the supply of energy in excess of maintenance, as through increasing the efficiency of energy metabolisability. As a consequence, there was a better relationship between dietary $\mathrm{NE}_{\mathrm{p}}$ rather than $\mathrm{AME}$ with bird
WG and FCE, further suggesting that $\mathrm{NE}_{\mathrm{p}}$ is a more predictive measure for assessing the value of supplementary phytase for poultry. The present experiment has shown that phytase increases the $\mathrm{NE}_{\mathrm{p}}$ of a diet. However, in a practical situation, an increased feed intake would also be expected, and this could further improve the economic value of the enzyme.

Birds fed the NC retained less total carcass energy and had the lowest $\mathrm{NE}_{\mathrm{p}}: \mathrm{HP}_{\mathrm{f}}$ value compared with all the other diets. The likely interpretation for such an increase in $\mathrm{NE}_{\mathrm{p}}: \mathrm{HP}_{\mathrm{f}}$ values is that dietary phytase will reduce the weight and the relative proportion of the gastrointestinal tract and other related organs when fed to broilers ${ }^{(30)}$, and reduce endogenous secretions ${ }^{(24,31)}$. Spratt et al. ${ }^{(32)}$ demonstrated that despite the fact that the liver and the gut account for approximately only $3 \%$ of the body weight of a hen, they may contribute up to $26 \%$ of the $\mathrm{HP}_{\mathrm{t}}$, suggesting that a relatively small reduction in the gastrointestinal tract size could account for a significant saving in maintenance energy. This suggests that birds fed phytase may have a lower heat increment, thereby allowing them to divert relatively more energy towards growth rather than maintenance.

In summary, the present results indicate that the effect of phytase on dietary $\mathrm{NE}_{\mathrm{p}}$ was best described as a linear relationship between increasing dose and increased $\mathrm{NE}_{\mathrm{p}}$ (estimated within the range of doses used in the present study). However, there was no significant response of dietary AME to supplementary phytase. Dietary $\mathrm{NE}_{\mathrm{p}}$ was more highly correlated with performance criteria than dietary AME, and it seems to be a more sensitive way to evaluate broiler response to phytase supplementation. As a result, previous studies that have focused on the effect of phytase on AME alone may well have underestimated the full value of phytase. However, the effect of supplementing a high dosage of phytase to diets based on different ingredients needs further investigation, as data from the present study only indicate the potential benefits of higher levels of phytase in maize/soya-based diets that were low in P.

\section{Acknowledgements}

Dr Paul Rose, Harper Adams University College, Shropshire, UK, is thanked for his advice concerning statistical analysis 
and for constructive discussions during the preparation of the manuscript. The present study was funded by AB Vista Feed Ingredients, Marlborough, Wiltshire, UK. Both authors contributed to the planning of the study. V. P. was involved in the design and execution of the study and also drafting of the manuscript. M. R. B. was involved in the design and revision of the manuscript. The authors declare that there are no conflicts of interest in the present study.

\section{References}

1. Cooke B (1987) The impact of declaration of the metabolizable energy (ME) value of poultry feeds. In Recent Advances in Animal Nutrition, pp. 19-26 [W Haresing and DJA Cole, editors]. London: Butterworths, University Press.

2. Johnson LF \& Tate ME (1969) The structure of myo-inositol pentaphosphates. Ann N Y Acad Sci 165, 526-532.

3. Nelson TS, Shieh TR, Wodzinsk RJ, et al. (1971) Effect of supplemental phytase on utilization of phytate phosphorus by chicks. J Nutr 101, 1289-1293.

4. Maenz DD \& Classen HL (1998) Phytase activity in the small intestinal brush border membrane of the chicken. Poult Sci 77, 557-563.

5. Applegate TJ, Angel R \& Classen HL (2003) Effect of dietary calcium, 25-hydroxycholecalciferol, or bird strain on small intestinal phytase activity in broiler chickens. Poult Sci 82, $1140-1148$.

6. De Groote G (1974) A comparison of a new net energy system with the metabolizable energy system in broiler diet formulation performance and profitability. Br Poult Sci 15, 75-95.

7. Farrell DJ (1999) In vivo and in vitro techniques for the assessment of the energy content of feed grains for poultry: a review. Aust J Agric Res 50, 881-888.

8. Pirgozliev V \& Rose SP (1999) Net energy systems for poultry feeds: a quantitative review. World Poult Sci J 55, 23-36.

9. MacLeod M (2002) Energy utilisation: measurement and prediction. In Poultry Feedstuffs: Supply, Composition and Nutritive Value, pp. 191-217 [J McNab and KN Boorman, editors]. London: CAB International.

10. Ravindran V, Selle PH \& Bryden WL (1999) Effects of phytase supplementation, individually and in combination, with glycanase, on the nutritive value of wheat and barley. Poult Sci 78, 1588-1595.

11. Shirley RB \& Edwards HM (2003) Graded levels of phytase past industry standards improves broiler performance. Poult Sci 82, 671-680.

12. Tejedor AA, Albino LFT, Rostagno HS, et al. (2001) Effect of phytase supplementation on the performance and ileal digestibility of nutrients. Rev Bras Zootec 30, 802-808.

13. Pirgozliev V, Bedford M, Acamovic T, et al. (2011) The effects of supplementary bacterial phytase on dietary energy and total tract amino acid digestibility when fed to young chickens. Br Poult Sci 52, 245-254.

14. National Research Council (1994) Nutrient Requirements of Poultry, 9th ed. Washington, DC: National Academic Press.

15. Short FJ, Gorton P, Wiseman J, et al. (1996) Determination of titanium dioxide added as an inert marker in chicken digestibility studies. Anim Feed Sci Technol 59, 215-221.
16. Tanner SD, Baranov VI \& Bandura DR (2002) Reaction cells and collision cells for ICP-MS: a tutorial review. Spectrochim Acta Part B Atom Spectrosc 57, 1361-1452.

17. McCance RA \& Widdowson EM (1935) Phytin in human nutrition. Biochem J 29, 2694-2699.

18. Association of Official Analytical Chemists (1994) Official Methods of Analysis, 16th ed. Washington, DC: Association of Official Analytical Chemists.

19. Okumura JI \& Mori S (1979) Effect of deficiencies of single essential amino acids on nitrogen and energy utilisation in chicks. Br Poult Sci 20, 421-429.

20. Olukosi OA, Cowleson AJ \& Adeola O (2008) Energy utilization and growth performance of broilers receiving diets supplemented with enzymes containing carbohydrase or phytase activity individually or in combination. Br J Nutr 99, 682-690.

21. Karadas F, Pirgozliev V, Pappas AC, et al. (2010) Effects of different dietary phytase activities on the concentration of antioxidants in the liver of growing broilers. J Anim Phys Anim Nutr 94, 519-526.

22. Daskiran M, Teeter RG, Fodge D, et al. (2004) An evaluation of endo-beta-D-mannanase (Hemicell) effects on broiler performance and energy use in diets varying in beta-mannan content. Poult Sci 83, 662-668.

23. Nian F, Guo YM, Ru YJ, et al. (2011) Effect of exogenous xylanase supplementation on the performance, net energy and gut microflora of broiler chickens fed wheat-based diets. Asian Aust J Anim Sci 24, 400-406.

24. Cowieson AJ, Wilcock P \& Bedford MR (2011) Super-dosing effects of phytase in poultry and other monogastrics. World Poult Sci J 67, 225-235.

25. Olukosi OA \& Adeola O (2008) Whole body nutrient accretion, growth performance and total tract nutrient retention responses of broilers to supplementation of xylanase and phytase individually or in combination in wheat-soybean meal based diets. J Poult Sci 45, 192-198.

26. Leeson S \& Summers JD (1997) Feeding programs for broilers. In Commercial Poultry Nutrition, 2nd ed., pp. 207-254 [S Leeson and JD Summers, editors]. Guelph: University Books.

27. Pirgozliev V, Mares P, Acamovic T, et al. (2006) Dietary phytase activities and the efficiency of energy utilisation in chickens. Poult Sci 85, 91.

28. Annison E, Hill K \& Kenworthy R (1968) Volatile fatty acids in the digestive tract of the fowl. Br J Nutr 22, 207-216.

29. Ravindran V, Cabahug S, Ravindran G, et al. (1999) Influence of microbial phytase on apparent ileal amino acid digestibility of feedstuffs for broilers. Poult Sci 78, 699-706.

30. Wu YB, Ravindran V, Thomas DG, et al. (2004) Influence of phytase and xylanase, individually or in combination, on performance, apparent metabolisable energy, digestive tract measurements and gut morphology in broilers fed wheat-based diets containing adequate level of phosphorus. Br Poult Sci 45, 76-84.

31. Pirgozliev V, Acamovic T \& Bedford MR (2009) Previous exposure to dietary phytase reduces the endogenous energy losses from precision-fed chickens. Br Poult Sci 50 , 598-605.

32. Spratt RS, McBride BW, Bayley HS, et al. (1990) Energy metabolism of broiler breeder hens. 2. Contribution of tissues to total heat production in fed and fasted hens. Poult Sci $\mathbf{6 9}$, 1348-1356. 